\title{
Peran Lingkungan dan Pola Asuh Orang Tua terhadap Pembentukan Karakter Anak Usia Dini
}

\section{Atik Latifah}

UIN Sunan Kalijaga Yogyakarta Jl. Laksda Adisucipto, Papringan, Caturtunggal, Sleman, Yogyakarta

Email: Atikltfh1992@gmail.com

\section{Naskah diterima: 15 Juni 2020, direvisi: 09 September 2020, diterbitkan: 23 September 2020}

\begin{abstract}
Abstrak
Anak usia dini merupakan masa keemasan golden age period bagi perkembangan seluruh aspek dalam kehidupannya baik itu perkembangan fisik, kognitif, sosial emosional dan pembentukan karakter pada anak. Pada pembentukan karakter anak usia dini ini membutuhkan peran penting pola asuh orang tua yang mana peran orang tua ini merupakan pilar utama dalam Pendidikan anak usia dini, karakter pada anak usia dini bisa berkembang dengan mendapatkan stimulus yang baik begitu pula sebaliknya bila stimulus yang buruk diberikan maka hal tersebut akan membentuk karakter yang buruk bagi anak usia dini, karena anak usia dini memiliki sikap yang spontan yang belum bisa membedakan perilaku baik maupun perilaku yang buruk. Adapun pengaruh dari luar yang bisa membentuk karakter pada anak usia dini yaitu pegaruh lingkungan, lingkungan sendiri terbagi atas tiga bagian yaitu lingkungan keluarga, sekolah, dan masyarakat. Metode penelitian yang digunakan dalam penelitian ini adalah penelitian kualitatif deskriptif. Adapun beberapa teknik pengumpulan data yang peneliti lakukan pada penelitian ini, yang diantaranya adalah observasi terstruktur, wawancara semi-terstruktur dengan menggunakan schedule questioner atau interview guide yang digunakan dalam melakukan wawancara dengan sumber penelitian.
\end{abstract}

Kata kunci: Lingkungan, Pola Asuh, Karakter.

\begin{abstract}
Early childhood is the golden age of the golden age period for the development of all aspects of life, including physical, cognitive, social emotional and character building in children. In the formation of early childhood character, it requires an important role in parenting, where the role of parents is the main pillar in early childhood education, character in early childhood can develop by getting good stimulus and vice versa if bad
\end{abstract}


stimulus is given then This will form a bad character for early childhood, because early childhood has a spontaneous attitude that cannot distinguish between good behavior and bad behavior. As for external influences that can shape early childhood characters, namely the environmental influence, the environment itself is divided into three parts, namely the family environment, school, and community. The research method used in this research is descriptive qualitative research. There are several data collection techniques that the researchers conducted in this study, which include structured observation, semi-structured interviews using a questionnaire schedule or interview guide used in conducting interviews with research sources.

Keywords: Environment, Parenting Pattern, Character.

\section{Pendahuluan}

Pendidikan anak usia dini merupakan bagian dari penerapan Pendidikan sepanjang hayat (long life education) yang merupakan portal utama dalam kehidupan. Masa usia dini sendiri merupakan "golden age period" artinya dalam hal ini adalah masa emas untuk seluruh aspek perkembangan manusia, baik fisik, kongnitif, sosial emosional dan lain sebagainya. Salah satu aspek perkembangan yang penting bagi anak usia dini adalah sosial emosional. Dalam praktiknya dalam kehidupan perkembangan anak usia dini berpengaruh terhadap lingkungan, faktor lingkungan yang mempengaruhi perkembangan karakter anak. Lingkungan itu sendiri terdiri atas tiga yakni lingkungan keluarga, lingkungan sekolah, dan lingkungan masyarakat.

Pendidikan anak usia dini sendiri terdapat beberapa pengaruh yang berkaitan dalam perkembangannya antara lain adalah pengaruh lingkungan serta di dukung oleh peran orang tua dalam membangun kepribadian anak ataupun karakter anak. Penyelenggaraan Pendidikan anak usia dini, diperlukan lingkungan yang berkualitas, sebab itu merupakan sarana prasarana yang bersignifikan. Dalam peraturan Mentri Pendidikan Nasional Republik Indonesia Nomor 58 Tahun 2009 Tentang standar Pendidikan Anak Usia Dini telah dituangkan bahwa sarana dan prasarana Pendidikan Anak Usia Dini ini harus meliputi beberapa prinsip didalamnyaantara lain : 1) aman, nyaman, terang, dan memenuhi kriteria kesehatan bagi anak; 2) sesuai dengan tingkat pperkembangan anak; dan 3) memanfaatkan potensi dan sumber daya yang ada di lingkungan sekitar, termasuk barang limbah atau bekas layak pakai, dengan lingkungan yang menyenangkan maka akan dapat berkembang baik sesuai dengan tumbuh kembang pada usianya. 
Pola asuh orang tua pada anak usia dini akan membentuk karakter ada anak, karenanya orang hendaknya memberikan stimulasi yang cukup bagi anak usia dini jikalau itu kurang akan mengakibatkan kemampuan sosialisi, bahasa, motorik halus dan kasar menjadi terlambat, maka dari itu lingkungan yang menunjang akan mendukung tumbuh kembang pada anak usia dini, proses pertumbuhan dan perkembangan seorang anak sangat pesat dan dapat berpengaruh bagi kehidupan selanjutnya. Anak pada masanya pembentukan biasanya akan di pengaruhi oleh faktor gentik dan lingkungan dalam membentuk karakter pada anak.

Banyak sekali problematika peran penting pola asuh orang tua bagi keberlangsungannya perkembangan anak usia dini, disamping kesibukan dari orang tua adapula orang tua yang belum memahami betapa pentingnya keterlibatan rang tua dalam mengasuh anak, hingga akhirnya mengakibatkan beberapa masalah bagi perkembangan anak di berbagai aspek. Dalam penelitian sebelumnya yang dilakukan oleh Uswatun Hasanah dengan judul penelitian Pola Asuh Orang tua dalam Membantuk Karakter Anak, yang mana menyebutkan bahwa karakter seseorang berkembang berdasarkan potensi yang dibawanya sejak dari lahir, akan tetapi semakin berkembangnya seorang apalagi anak usia dini, perkmenbangan anak juga melibatkan peran dari orang tua yang mana dibutuhkan dalam membentuk perkembangan dari karakter seorang anak, bahwa pola asuh dari orang tua dapat mempengaruhi dan membentuk pribadi dari seorang anak secara signifikan (Hasanah, 2016). Hal ini juga terbukti, Berdasarkan dari pengalaman penulis mengajar disebuah Lembaga Pendidikananak usia dini, peran penting dan pola asuh orang tua bagi perkembangan karakter anak usia dini sangat berpengaruh pada perkembangan aspek yang ada pada anak usia dini. Pada kenyataannya kepedulian orang tua terhadap tingkat perkembangan anak yang masih minim, yang disebabkan oleh beberapa faktor yang diantaranyadatang dari orang tua, lingkungan sekolah, masyarakat dan beberapafaktorlainnya.

Dalam hal ini, oleh karena itu peran penting orang tua dalam pembentukan karakter anak perlu diperhatikan sebab pola asuh memiliki hubungan erat dengan sebuah keberhasilan Pendidikan anak, akantetapi disisi lain juga mempunyai hubungan erat dengan kenakalan remaja (SKM, 2019). Seorang anak dilahirakan di dunia ini membawa harapan yang banyak bagi orang tua, salah satu diantaranya adalah anak sendiri merupakan invenstasi bagi kedua orang tuanya untuk memiliki karakter yang baik yang sesuai dengan apa yang orang tua inginkan, oleh karenanya dalam tumbuh kembang dari seorang anak perlu banyak melibatkan peranan lingkungan dan pola asuh dari orang tua. Berdasarkan dari paparan di atas, dalam 
tulisan ini ditujukan untuk mengakaji pengaruh lingkungan dan pola asuh dari orang tua terhadap perkembangan karakter bagi anak usia dini.

\section{Metodologi}

Jenis penelitian ini dengan menggunakan penelitian kualitatif deskriptif. Dan dalam penelitian ini subjek yang dituju adalah anak-anak yang ada di Lembaga Pendidikan PAUD Insan Mulia Dua Ngemplak Sleman yang kesehariannya lebih banyak berada disekolah, sumber data yang digunakan pada penelitian ini adalah guru kelas, kepala sekolah dan wali murid. Adapun beberapa teknik pengumpulan data yang peneliti lakukan pada penelitian ini, yang diantaranya adalah observasi terstruktur, wawancara semi-terstruktur dengan menggunakan schedule questioner atau interview guide yang digunakan dalam melakukan wawancara dengan sumber penelitian(Astuti \& Aziz, 2019), serta dalam menganalisis data menggunakan model dari Miles dan Huberman Adapun beberapa tahapan dalam analisis ini yaitu, pengumpulan data, reduksi data dan penarikan kesimpulan(Mathew \& Huberman, 1992).

\section{Hasil dan Diskusi}

Perkembangan pada anak usia dini dapat diartikan pula sebagai proses tranmisi dari konstitusi psiko-fisik yang herediter, dirangsang oleh faktor - faktor lingkungan yang menguntungkan, dalam perwujudan proses aktif-menjadi secara kontinu(Kartono, 1995), sebagai bentuk perilaku kolektif seorang anak dengan perilaku kerjasama dengan orang lain. Pada proses perkembangannya anak usia dini lingkungan menjadi faktor yang sangat penting setelah faktor hereditas atau keturunan, sebab tanpa adanya dukungan dari faktor lingkungan maka proses perkembangan dalam mewujudkan potensi hereditas atau keturunan menjadi kemampuan yang tidak akan terjadi.

Dalam pengertiannya lingkungan berarti kondisi yang berada disekitar kita, pada Pendidikan sendiri arti dari lingkungan itu sendiri sangatlah luas, yang mana kondisi sesuatu berada di luar diri anak usia dini. Perkembangan anak usia dini juga berpengaruh dari beberapa faktor lingkungan yang mempengaruhinya, diantaranya faktor-faktor tersebut adalah sebagai berikut. 


\section{Lingkungan Keluarga}

Lingkungan keluarga merupakan pilar yang utama pada perkembangan anak usia dini dalam membentuk baik buruknya pribadi manusia agar berkembang baik dalam beretika, moral dan akhlaknya. Peran keluarga dalam membentuk pola sikap pribadi seorang anak yang menentukan proses Pendidikan yang di peroleh anak, tidak hanya dalam sekolah melainkan pada semua faktor yang bisa dijadikan sumber Pendidikan bagi anak(Mutmainnah, 2019). Faktor yang menyebabkan peran keluarga sangat penting dalam proses perkembangan anak adalah sebagai berikut.

a. Keluarga merupakan kelompok kecil yang anggotanya berinteraksi face to face secara tertutup.

b. Orang tua mempunyai motivasi kuat untuk memdidik anak karena anak merupakan buah dari kasih saying hubungan antara suami dan istri.

c. Karena hubungan sosial dalam keluarga yang tertutup.

Fungsi sosialisasi menunjukan peran keluarga dalam membentuk kepribadian anak. Melalui interaksi sosial dalam keluarga, anak mempelajari pola-pola sikap, tingkah laku, keyakinan, cita-cita, dan nilai-nilai di masyarakat dalam rangka perkembangan kepribadiannya.

Lingkungan keluarga harus dapat menyiapkan dan memberikan Pendidikan untuk anaknya agar menjadi generasi penerus yang baik. Pendidikan merupakan proses pengembangan potensi individu, pewarisan budaya dan interaksi antar potensi individu, kelompok dengan lingkungan masyarakat luas(Langgulung, 2004). Sehingga anak yang berkembang dengan baik akan mengambarkan kondisi dari faktor berpengaruhnya perkembangan dari lingkungan keluarga. Berhasil tidaknya Pendidikan seorang anak dapat dihubungkan dengan perkembangan sikap dan pribadi dari orang tuanya serta hubungan komuikasi pola asuh dalam keluarganya, lingkungan keluarga dapat berperan penuh terhadap perkembangan untuk memberikan sistem Pendidikan secara komerhensif yang saling berkesinambung.

Anak sebagai karunia dari Allah SWT yang sekaligus merupakan amanah, harus diapresiasi dengan rasa syukur mendalam yang diimplementasikan dalam bentuk ketulusan untuk merawat dan membimbingnya menjadi Tangguh, memliki kepekaan sosial yang tinggi dan agar perkembangannya berkembang dengan baik. Pembentukan perilaku, sikap, kebiasaan, penanaman nilai, dan perilaku sejenisnya lingkungan keluarga sendiri bisa 
memberikan pengaruh yang dominan terhadap perkembangan pada tumbuh kembang anak terlebih pada anak usia dini yang mana mereka masih dianggap suci.

Adapun tujuan dari peran lingkungan keluarga dalam pembetukan perkembangan pada anak usia dini, yaitu orang tua mengajarkan kepada anaknya tentang:

a. Penguasaan diri

Masyarakat menuntut penguasaan diri setiap anggotanya. Proses mengajar anak untuk menguasai dirinya timbul pada saat orang tua melatih anak untuk memelihara kebersihan dirinya.

b. Nilai

Nilai dasar dalam diri seseorang terbentuk pada saat usia enam tahun bersamaan dengan Latihan penguasaan diri.

c. Peranan sosial

Setelah pada diri sendiri anak berkembang kesadaran diri sendiri yang membedakan dirinya dengan orang lain, diamulai mempelajari peranan sosial yang sesuai dengan gambaran tentang dirinya. Alat Pendidikan yang digunakan keluarga adalah kasih sayang dan kewibawaan. Kasih sayang orang tua berperan melindungi anak dalam hal ketidak berdayaannya. Dengan dilandasi oleh kasih sayang, anak akan merasa terlindungi dan merasaaman, memungkinkan anak akan tumbuh dan berkembang dengan secara baik.

\section{Lingkungan Sekolah}

Pendidikan anak Usia Dini adalah jenjang Pendidikan sebelum memasuki jenjang Pendidikan selanjutnya yang merupakan suatu upaya pembinaan yang bertujuan bagi anak sejak lahir sampai dengan usia enam tahun yang dilakukan pemberiang rangsangan Pendidikan untuk membantu pertumbuhan dan perkembangan.

Pendidikan ini merupakan salah satu bentuk penyelenggaraan Pendidikan yang menitik beratkan pada peletakan dasar kearah pertumbuhan dan enam perkembangan yakni: agama dan moral, fisik motorik, kongnitif, bahasa,s sosial emosional dan seni. Perkembangan setiap anak tidak sama karena setiap individu memiliki perkembangan yang berbeda. Makanan yang bergizi dan seimbang serta stmulasi yang insentif sangat dibutuhkan dalam pertumbuhan dan perkembangan pada anak usia dini. Dan apabila anak diberikan stimulasi yang baik akan dapat melaksanakan tugasnya dengan baik. 
Menurut Psikologi terdapat 10 pengaruh Pendidikan bagi perkembangan anak usia dini, diantaranya:

1. Megalami perubahan yang disadari dan disengaja (intensional)

Perubahan perilaku ini merupakan perubahan yang terjadi atas kesadaran dan factor kesengajaan yang dilakukan oleh individu yang bersangkutan. Karena memang dilakukan dengan sadar dan sengaja, maka individu tersebut juga tentunya mengetahui dan menyadari perubahan yang terjadi dalam dirinya atas perubahan yang sudah dialakukan atas hidupnya.

2. Mengalami perubahan yang berkesinambungan (continue)

Yaitu bertambahnya pengetahuan dan keterampilan dalam Pendidikan yang dimiliki oleh setiap individunya tentunya meruakan kelanjutan dari pengetahuan dan keteramilan yang telah diperoleh sebelumnya. Begitu juga dengan pengetahuan, sikap dan pengetahuan yang diperoleh tersebut akan menjadi dara bagi pengembangan pengetahuan yang akan dapat oleh individu tersebut di masa mendatang yang bersifat berkesinambungan.

3. Mengalami perubahan yang fungsional setiap perilaku yang terjadi dapat dimanfaatkan untuk kebaikan dan kepentingan individu yang bersangkutan, baik untuk kepentingan masa sekarang maupun masa yang akan datang, yang bisa diaplikasikan dalam kehidupan.

4. Mengalami perubahan yang bersifat aktif untuk mendapatkan perilaku yang baru dan tentunya lebih baik dari sebelumnya, tentunya individu yang bersangkutan tersebut untuk melakukan dan mengupayakan perubahan dalam dirinya. Contohnya apabila ingin memiliki keterampilan dalam suatu bidang, maka individu tersebut harus mengupayakan atau melakukan usaha dalam bidang yang dihendaki tersebut.

5. Mengalami perubahan yang bersifat permanen

Perubahan perilaku yang diperoleh dari proses belajar cenderung menetap dan akan menjadi bagian yang melekat atau menyatu dalam diri individu tersebut. Misalnya ada seorang anak mempelajari seni melukis, maka bisa saja seni melukis ini akan melekat dalam dirinya selamanya.

6. Mengalami perubahan yang bertujuan dan terarah

Apabila anda ingin belajar pastinya anda akan menginginkan hal yang hendak dicapainya. Begitupun dengan anak anda, anda melakukan pengajaran pastinya pastinya ada hasil yang anda harapkan yang dapat membekali pendidikan anak anda nantinya. Pendidikan 
pada anak ini pun berfungsi untuk jangka pendek menegah dan juga dalam jangka panjang nantinya. Karena memang pendidikan itu berlaku seumur hidup.

7. Mengalami perubahan perilaku secara keseluruhan

Seperti yang sudah kita ketahui bersama, perubahan yang didapat setiap individu pada saat mengikuti pendidikan bukan hanya perubahan pada pengetahuan semata, tetapi di samping itu termasuk juga perubahan mental sikap dan keterampilannya yang mengarah ke tujuan yang lebih baik.

8. Mengalami perubahan kecakapan intelekual

Salah satu hal penting dari psikologis pendidikan ini adalah dapat mengarahkan setiap individu untuk mendapatkan kecakapan intelektual. Maksudnya adalah apabila anak anda aktif dalam psikologis pendidikan ini, maka tidak menutup kemungkinan anak anda akan keterampilan dalam melakukan interaksi dengan lingkungan sekitarnya dengan menggunakan simbol-simbol. Misalnya saja dengan menggunakan symbol matematika. Seorang yang memiliki intelektual yang tinggi cenderung lebih menyukai gambar atau simbol dibanding dengan tulisan, karena bagi mereka itu lebih menarik.

9. Mengalami perubahan pada kecapakan motoriknya

Kecakapan motorik merupakan hasil belajar yang berupa kecakapan pergerakan yang dikontrol oleh otot dan fisik. Seperti yang penulisan jelaskan sebelumnya, bahwasahnya psikologis ini tidak hanya berbicara pada pendidikan yang bertambah pada anakanda, tetapi juga perubahan yang terjadi pada jenislainnya.

10. Mengalami perubahan di sengaja aspek kehidupan individu yang bersangkutan,

Secara umum, apabila seseorang anak mengikuti psikologis pendidikan, bukan hanya pendidikan dan pengetahuan akan pelajaran yang akan bertambah. Tetapi pada umumnya semua aspek dalam dirinya akan berubah kearah yang lebih baik(Yusuf \& Jurniati, 2018). Dalam penyelenggaraan PAUD, sebaiknya lingkungan diarahkan untuk menjadi lingkungan yang sesuai dengan kaidah keberlangsungan Pendidikan untuk anak usia dini, sebab hal ini sudah tercantum dalam Dalam Peraturan Menteri Pendidikan Nasional Republik Indonesia Nomor 58 Tahun 2009 tentang Standar Pendidikan Anak Usia Dini telah dituangkan bahwa sarana prasarana di PAUD hendaknya memenuhi prinsip-prinsip berikut: 1) aman, nyaman, terang, dan memenuhi kriteria kesehatan bagi anak; 2) sesuai dengan tingkat perkembangan anak; dan 3) memanfaatkan potensi dan sumber daya yang ada di lingkungan sekitar, termasuk barang limbah atau bekas layak pakai. 
Dalam pelaksanaannya Pendidikan bagi anak usia diani yang menyenangkan menurut Montessori memiliki beberapa karakteristik yakni :

a. Accessibility and availability (mudahdiakses dan tersedia)

b. Freedom of movement and choice (adakebebasanbergerak dan memilih)

c. Personal responsibility (penuhtanggungjawab personal

d. Reality and nature (nyata dan alami)

e. Beauty and harmony (indah dan selaras) (Isaac, 2010)

Penyediaan lingkungan sekolah yang baik akan membawa pada pengaruh perkembangan pendidiakn anak usia dini.

\section{Lingkungan Masyarakat}

Masyarakat merupakan bagian dari kehidupan yang tidak bisa dipisahkan, dalam perktiknya dikehidupan kita saling memerlukan satu dengan lainnya, banyak hal yang terlibat terutama komunikasi, dalam hal ini masyarakat juga berperan aktif pada keberlangsungan perkembangan bagi anak usia dini.

Masyarakat adalah sekelompok manusia yang secara relatif mandiri, hidup bersamasama dalam waktu yang cukup lama, mendiami suatu tertentu, memiliki kebudayaan yang sama, dan melakukan sebagian besar kegiatannya dalam kelompok tersebut(Horton, 1999).

Masyarakat merupakan tempat anak-anak untuk berkembang dan bergaul dengan anak-anak lainnya atau teman sebaya dan orang dewasa, namun dengan demikian adapun beberapa faktor yang akan berpengaruh pada perkembangan anak usia dini, diantaranya adalah:
a. Teman sebaya
b. Culture atau budaya yang ada di masyarakat itu sendiri
c. Media masa

Dengan begitu dalam membentuk karakter dari seorang anak usia dini ini perlu kehatihatian agar tidak salah pada pola pengasuhannya.Sebab yang terjadi saat ini banyak orang tua yang acuh dengan perkembangan anak, mereka lebih banyak melibatkan sekolah sebagai sarana pembentukan karakter pada anak usia dini. Peran penting bagi perkembangan seorang anak adalah dengan melibatkan pola asuh yang baik serta lingkungan yang baik untuk mendukung tumbuh kembangnya. 


\section{Perkembangan Karakter Anak Usia Dini}

Pembentukan karakter pada anak usia dini mengalami banyak perubahan salah satunya dengan adanya peran pola asuh orang tua dan pengaruh dari lingkungan. Ada beberapa hal yang perlu disadari bahwa anak usia dini pertama kali mendapatkan pelajaran justru dari keluarga. Peran seorang keluarga ini mampun membawa sikap karakter anak.

Dalam menjalani hubungan petemanan akan hal positif maupun negatif, itu semua bergantung pada pengalaman seorang anak melalui peran penting pola pengasuhan dari orang tua (Puspitasari et al., 2015), pola asuh sendiri dapat diartikan sebagai cara merawat dan mendidik anak, pada keluarga peran seorang ibu menjadi salah satu dominan yang terbaik (Robbiyah et al., 2018).

Adapun hal lain yang mempengaruhi keberhasilan perkembangan karakter pada anak usia dini adalah adanya pengaruh dari lingkungan keluarga, sekolah, dan masyarakat. Untuk mendukung sebuah pencapaian karakter pada anak lingkungan sekolah juga sangat berperan penting dalam proses belajarsiswa, serta memberikan sarana dan prasarana yang memadai bagi keberlangsungan setiap proses pembelajaran (Jessicasari \& Hartati, 2014). Lingkungan sebagai salah satu upaya dalam proses pembentukan karakter seorang anak, maka dengan itu pengaruh dari lingkungan ini juga merupakan tantangan bagi orang tua masa kini, sebab jika salah sedikit saja itu pula yang akan mempengaruhi perkembangannya.

Untuk mendapatkan hasil yang maksimal pada proses penanaman sebuah karakter pada anak usia dini, maka dengan itu pihak Lembaga sekolah hendaknya berkerjasama dengan orang tua melalui penerapan polaasuh yang tepat bagian anak usia dini(Riati, 2016). Peran penting dari pola asuh orang tua dan lingkungan menajadi salah satu peran penting bagi terbentuknya pola asuh bagi seorang anak, dengan hal ini orang tua diharapkan mampu memberikan sikap yang selektif dalam menerapkan pola asuh yang tepat bagi keberlangsungan perkembangan karakter pada anak. Akan tetapi jika orang tua terlalu abai dengan pergerakan zaman itupula akan mempengaruhi pada perkembangan karakter dari seorang anak.

Pada harfiahnya anak usia dini memiliki karakteristik yang unik yang khas, baik itu secara psikis, sosial, moral, dan lain sebagainya. Masa kanak-kanak merupakan masa yang paling penting dari seluruh hidupnya, sebab pada masa ini adalah proses pembentukan sebuah dasar fondasi yang akan terus dibawanya hingga dewasa nanti (Sinaga, 2018) 


\section{Penutup}

Anak usia dini merupakan bagian dari penerapan Pendidikan sepanjang hayat (long life education) masa usia dini sendiri juga disebut sebagai masa keemasan golden ageperiod yang mana pada masa ini perkembangan anak berkembang pada seluruh aspek baik fisik, kognitif, sosial emosional dan lain sebagainya. Maka dari itu untuk membantu perkembangan pada anak usia dini ini memerlukan peran penting pola asuh dari orang tua untuk tumbuh kembang mereka. Perkembangan karakter ada anak usia dini juga di pengaruhi oleh beberapa faktor yang di antara adalah faktor lingkungan.

\section{Daftar Pustaka}

Astuti, R., \& Aziz, T. (2019). Integrasi Pengembangan Kreativitas Anak Usia Dini di TK Kanisius Sorowajan Yogyakarta. Jurnal Obsesi : Jurnal Pendidikan Anak Usia Dini, 3(2), 294. https://doi.org/10.31004/obsesi.v3i2.99

Hasanah, U. (2016). Pola asuh orangtua dalam membentuk karakter anak. Elementary: Jurnal Ilmiah Pendidikan Dasar, 2(2), 72-82.

Horton. (1999). Sosiologi (Edisi Keen). Erlangga.

Isaac. (2010). Brigining the Montessori Approach to Your Early Years Practice. Routledge.

Jessicasari, A., \& Hartati, S. C. Y. (2014). Pengaruh Pola Asuh Orang Tua dan Lingkungan Sekolah terhadap Kedisiplinan Siswa Dalam Pembelajaran Pendidikan Jasmani, Olahraga dan Kesehatan (Studi pada kelas XI di SMAN 3 Sidoarjo). Jumal Pendidikan Olahraga Dan Kesehatan, 02(03), 661-666. http://ejournal.unesa.ac.id/index.phppendidikan-jasmani/issue/archive

Kartono, K. (1995). Psikologi Anak. Mandar Maju.

Langgulung, H. (2004). Pendidikan Islam Dalam Abad Ke 21. PT Pustaka Al-husna Baru.

Mathew, M. B., \& Huberman, M. (1992). Analisis Data Kualitatif Buku Sumber Tentang MetodeMetode Baru. UIP.

Mutmainnah, M. (2019). Lingkungan Dan Perkembangan Anak Usia Dini Dilihat Dari 
Perspektif Psikologi. Gender Equality: International Journal of Child and Gender Studies, 5(2), 15. https://doi.org/10.22373/equality.v5i2.5586

Puspitasari, R., Hastuti, D., \& Herawati, T. (2015). Pengarub Pola Asub Disiplin Dan Pola Asub Spiritual Ibu Terbadap Karakter Anak Usia Sekolah Dasar. 2, 208-218. https://doi.org/10.21831/jpk.v0i2.8624

Riati, I. K. (2016). Pengaruh Pola Asuh Orangtua Terhadap Karakter Anak Usia Dini. Jurnal Pendidikan, 4(2).

Robbiyah, R., Ekasari, D., \& Witarsa, R. (2018). Pengaruh Pola Asuh Ibu terhadap Kecerdasan Sosial Anak Usia Dini di TK Kenanga Kabupaten Bandung Barat. Jurnal Obsesi: Jurnal Pendidikan Anak Usia Dini, 2(1), 74. https://doi.org/10.31004/obsesi.v2i1.10

Sinaga, R. (2018). Pendidikan Karakter pada Anak Usia Dini. Societas Dei: Jurnal Agama Dan Masyarakat, 5(2), 180. https://doi.org/10.33550/sd.v5i2.89

SKM, N. M. (2019). Hubungan Pola Asuh Orang Tua dengan Kenakalan Remaja. Journal of Chemical Information and Modeling, 53(9), 1689-1699. https://doi.org/10.1017/CBO9781107415324.004

Yusuf, M., \& Jurniati. (2018). Pengaruh Pendidikan bagi Perkembangan Anak Usia Dini. Tunas Cendekia, 1(1), 31-38. https://ejournal.iainpalopo.ac.id/index.php/tunascendekia/article/view/375 